\title{
Storage protein profile and amino acid content in wild rice Oryza glumaepatula
}

\author{
Karina Freire D'eça Nogueira Santos(1), Ricardo Diógenes Dias Silveira( ${ }^{(1)}$, \\ Claudia Cristina Garcia Martin-Didonet ${ }^{(2)}$ and Claudio Brondani( ${ }^{(3)}$
}

\begin{abstract}
(1)Universidade Federal de Goiás, Instituto de Ciências Biológicas, Campus II, saída para Nerópolis, Km 13, CEP 74001-970 Goiânia, GO, Brazil. E-mail: kabiomol@gmail.com, ricardo_biologia@hotmail.com (2)Universidade Estadual de Goiás, Departamento de Farmácia, BR 153, Km 99, CEP 75132-400 Anápolis, GO, Brazil. E-mail: cladido@gmail.com ${ }^{(3)}$ Embrapa Arroz e Feijão, Rodovia GO- 462, Km 12, Caixa Postal 179, CEP 75375-000 Santo Antônio de Goiás, GO, Brazil. E-mail: claudio.brondani@embrapa.br
\end{abstract}

\begin{abstract}
The objective of this work was to determine the total protein profile and the contents of the four major protein fractions (albumin, globulin, prolamin and glutelin) and of the amino acids in the endosperm of the rice wild species Oryza glumaepatula. The experiment was performed with 29 accessions of this species, collected from 13 Brazilian locations, and two commercial cultivars. Protein samples were prepared using dried, polished, and ground grains to obtain homogeneous, dry flour used in the preparation of extracts. Oryza glumaepatula accessions were identified with the highest levels of total protein, albumin and glutelin protein fractions, and amino acids (with the exception of tryptophan) in comparison to the two analized rice cultivars. The albumin and glutelin profiles in SDS-Page were distinct between rice cultivars and O. glumaepatula. This wild species has the potential to increase the nutritional quality of rice storage protein through interspecific crosses.
\end{abstract}

Index terms: Oryza sativa, genetic resources, nutritional quality, plant breeding, SDS-Page.

\section{Perfil da proteína de reserva e conteúdo de aminoácidos no arroz silvestre Oryza glumaepatula}

\begin{abstract}
Resumo - O objetivo deste trabalho foi determinar os perfis de proteína total e o conteúdo das quatro principais frações proteicas (albumina, globulina, prolamina e glutelina) e de aminoácidos no endosperma da espécie de arroz silvestre Oryza glumaepatula. O experimento foi realizado com 29 acessos dessa espécie, coletados em 13 locais no Brasil, e duas cultivares comerciais. Amostras de proteínas foram preparadas com grãos secos, polidos e moídos, para obtenção de uma farinha seca e homogênea, usada no preparo dos estratos. Acessos de O. glumaepatula foram identificados com os maiores níveis de proteína total, frações proteicas de albumina e glutelina, e aminoácidos (com exceção do triptofano), em comparação às duas cultivares de arroz avaliadas. Os perfis de albumina e glutelina em SDS-PAGE foram distintos entre as cultivares de arroz e O. glumaepatula. Essa espécie silvestre tem o potencial de aumentar a qualidade nutricional da proteína de reserva do arroz por meio de cruzamentos interespecíficos.
\end{abstract}

Termos para indexação: Oryza sativa, recursos genéticos, qualidade nutricional, melhoramento de plantas, SDS-Page.

\section{Introduction}

The genus Oryza has two cultivated species (Oryza sativa and $O$. glaberrima) and 21 wild species, which are distributed in tropical and subtropical regions. In Brazil, there are four species of wild rice - O. glumaepatula (AA), O. alta (CCDD), O. grandiglumis (CCDD), and O. latifolia (CCDD) (Rangel et al., 2007). Among these four species, O. glumaepatula has attracted more interest, especially regarding the possibility of its use as a gene reservoir, since it has a diploid genome, which makes feasible interspecific crossing with the cultivated species $O$. sativa. In addition, it is adapted to Brazilian soil and climate (Brondani et al., 2005). In Brazil, the development of interspecific lines of $O$. sativa x O. glumaepatula began in 1995. These strains, derived from two backcrosses using rice cultivars as recurrent parents, have some agronomically interesting characteristics, such as fast vegetative growth and increased yield potential (Rangel et al., 2007).

Analysis of encoded proteins by the genome, also known as proteome, is a powerful molecular tool for studying complex biological processes in organelles, cells, organs, and tissues (Komatsu \& Tanaka, 2005). 
Rice is a model plant for genomic and proteomic studies, due to its small genome compared with other cereals. In recent years, there has been a significant progress in the identification and cataloging of rice proteins. More than thirteen thousand proteins, expressed in different tissues and organelles, have been detected, out of which 5,755 have been classified and had their functions determined (Komatsu, 2006). Information on the rice proteome is available in databases such as the Rice Proteome Database (National Institute of Agrobiological Sciences, 2002). However, there is little information on grain storage proteins in these databases (Komatsu, 2006).

Storage proteins accumulate in large quantities during seed development and are mainly stored in special organelles called protein bodies (Halford \& Shewry, 2002). As shown by Kim et al. (2009), the total storage protein content in $O$. sativa endosperm varies between 4.3 and $18.2 \%$. These storage proteins are divided into four fractions according to their differences in solubility: albumins (soluble in water), globulins (soluble in salts), prolamin (soluble in alcohol), and glutelin (soluble in acidic or basic solutions) (Shotwell \& Larkins 1989). Glutelin fraction is the predominant protein in rice endosperm, and is classified according to the molecular weights of $\alpha$-glutelin $(37 \mathrm{kDa})$ and $\beta$-glutelin (20 kDa) (Katsude-Tanaka et al., 2004).

Rice protein is considered to be of good quality because it contains eight out of ten essential amino acids. Compared with other cereals, such as maize and wheat, rice has a high level of lysine, which provides high digestibility and nutritional quality (Huebner et al., 1990). Determining the contents of amino acids in storage proteins is an excellent source of information for planning the development of rice genotypes with higher grain nutritional quality. In Brazil, rice accounts for $14 \%$ of the energy and $10 \%$ of the protein consumed daily by the population (Naves \& Bassinello, 2006). The identification of high-protein $O$. glumaepatula genotypes, and the development of interspecific lines from this species, could further increase protein content and nutritional quality of rice.

The objective of this work was to determine the total protein profiles and the contents of four major protein fractions (albumin, globulin, prolamin and glutelin) and of the amino acids in the endosperm of the rice wild species $O$. glumaepatula.

\section{Materials and Methods}

Twenty nine accessions of the wild rice species Oryza glumaepatula, collected from five Brazilian states: Goiás (GO), Mato Grosso (MT), Mato Grosso do Sul (MS), Amazonas (AM), and Roraima (RR) were evaluated (Table 1). A total of 200 panicles were collected from each population, with an average of 40 seeds per panicle. Forty seeds of each population were germinated on paper rolls. After one week, seedlings were transplanted to pots and cultivated in greenhouse, in order to increase the availability of seeds, which were stored later in the genebank of Embrapa (Brazilian Agricultural Research Corporation).

Seed samples of each population were analyzed. As controls, the upland rice cultivars BRS Bonança and Primavera, chosen due to their high yield and to

Table 1. Collecting locations and germplasm storage sites of the 29 Oryza glumaepatula accessions analyzed.

\begin{tabular}{|c|c|c|}
\hline Accession & State/City & Storage site \\
\hline BGA 14280 & Goiás/Uruana & Santo Antônio Farm \\
\hline BGA 14232 & Goiás/Itapirapuã & Córrego Fundo Farm \\
\hline BGA 14233 & Goiás/Itapirapuã & Córrego Fundo Farm \\
\hline BGA 14160 & Amazonas & Lake Caiambé - Solimões River \\
\hline BGA 14162 & Amazonas & Lake Tefé - Solimões River \\
\hline BGA 14170 & Amazonas & Lake Caldeirão - Solimões River \\
\hline BGA 14137 & Amazonas & Island Trocarí - Solimões River \\
\hline BGA 14179 & Mato Grosso do Sul & Codraza - Ladário - Paraguai River \\
\hline BGA 14188 & Mato Grosso do Sul & Porto Manga - Taquarí River \\
\hline BGA 14187 & Mato Grosso do Sul & Porto Manga - Taquarí River \\
\hline BGA 14186 & Mato Grosso do Sul & Porto Manga - Taquarí River \\
\hline BGA 14268 & Mato Grosso/Poconé & Transpantaneira Highway \\
\hline BGA 14270 & Mato Grosso/Poconé & Transpantaneira Highway \\
\hline BGA 14269 & Mato Grosso/Poconé & Transpantaneira Highway \\
\hline BGA 14210 & Roraima/Boa Vista & BR-174 Highway, Km $626^{(1)}$ \\
\hline BGA 14204 & Roraima/Boa Vista & Santa Glória Farm ${ }^{(1)}$ \\
\hline BGA 14202 & Roraima/Boa Vista & Campo Alegre Farm ${ }^{(1)}$ \\
\hline BGA 14203 & Roraima/Boa Vista & Novo Destino Farm ${ }^{(1)}$ \\
\hline BGA 14197 & Roraima/Boa Vista & Road to Boa Vista/Taiano ${ }^{(1)}$ \\
\hline BGA 14195 & Roraima/Boa Vista & BR 174 Highway, Km 575(1) \\
\hline BGA 14200 & Roraima/Boa Vista & Campo Alegre Farm ${ }^{(1)}$ \\
\hline BGA 14198 & Roraima/Boa Vista & Road to Vila São Francisco ${ }^{(2)}$ \\
\hline BGA 14199 & Roraima/Boa Vista & Road to Vila São Francisco ${ }^{(2)}$ \\
\hline BGA 14206 & Roraima/Cacaraí & National Park Viruá - Capinarana area \\
\hline BGA 14207 & Roraima/Cacaraí & BR 174 Highway - Manaus/Boa Vista \\
\hline BGA 14201 & Roraima/Boa Vista & Campo Alegre Farm ${ }^{(1)}$ \\
\hline BGA 14196 & Roraima/Boa Vista & BR-174 Highway, Km 560 ${ }^{(1)}$ \\
\hline BGA 14205 & Roraima/Alto Alegre & Road São Vicente/Alto Alegre ${ }^{(1)}$ \\
\hline BGA 14208 & Roraima/Normandia & Road Normandia/Surumum ${ }^{(1)}$ \\
\hline Primavera & Cultivated & - \\
\hline BRS Bonança & Cultivated & - \\
\hline
\end{tabular}

${ }^{(1)}$ Vereda de Lavrado. ${ }^{(2)}$ Collection roadside 
the fact that they are widely cultivated in Brazil, were used. The 29 wild accessions were quantitatively and qualitatively analyzed (SDS-Page) for total protein and major protein fractions. Protein samples were prepared using dried, polished grains, which were ground, and defatted with acetone, to obtain a homogeneous, dry flour for the preparation of extracts. Sequential extraction of total proteins and protein fractions was performed as described by Turley \& Ching (1986). Protein levels were quantified as described by Bradford (1976). The quantification of total protein and protein fractions was performed in triplicate, using three independent replicates of each accession, in a completely randomized design. The statistical analysis was carried out using the software Genes (Cruz, 2001). After the analysis of variance, the means were compared using the Scott-Knott test, at 5\% probability.

For comparison, a calibration curve with BSA (bovine serum albumin) was done at concentrations from 2.5 to $40 \mu \mathrm{g} \mathrm{L}^{-1}$. Physicochemical analysis of the amino acids was performed as described by Hagen et al. (1989).

Preparation of total protein samples for the qualitative analysis was made in denaturing polyacrylamide gel, using $20 \mathrm{mg}$ of flour and $350 \mu \mathrm{L}$ of sample buffer $\left[10 \mathrm{mmol} \mathrm{L}^{-1}\right.$ Tris $\mathrm{HCl}(\mathrm{pH} 6.8), 1 \%$ $\beta$-mercaptoethanol (v/v), 2\% SDS (w/v), 3\% glycerol $(\mathrm{v} / \mathrm{v})$ and bromophenol blue]. Then, samples were boiled for $10 \mathrm{~min}$ to denature proteins, in order to run SDS-Page analysis.

For albumin extraction, we used $100 \mathrm{mg}$ of the flour added to $500 \mu \mathrm{L}$ of $10 \mathrm{mmol} \mathrm{L}^{-1}$ Tris- $\mathrm{HCl}$ solution (pH 7.5) and $1 \mathrm{mmol} \mathrm{L}^{-1}$ EDTA. This solution was shaken for one hour and centrifuged $(13,000 \mathrm{rpm}$ for $15 \mathrm{~min}$ at $4^{\circ} \mathrm{C}$ ). The supernatant (albumin) was collected and precipitated with $1.5 \mathrm{~mL}$ of cold acetone, homogenized by inversion, and stored overnight in a freezer at $-20^{\circ} \mathrm{C}$. The solution was centrifuged at $15^{\circ} \mathrm{C}$ for 15 min, and the supernatant (acetone) was discarded. The pellet (albumin) was stored in a freezer for subsequent analysis on SDS-Page. For globulin extraction, $500 \mu \mathrm{L}$ of $10 \mathrm{mmol} \mathrm{L}^{-1}$ Tris-HCl (pH 7.5), $1 \mathrm{mmol} \mathrm{L}^{-1}$ EDTA, and $0.5 \mathrm{~mol} \mathrm{~L}^{-1} \mathrm{NaCl}$ were added to the initial flour. This solution was shaken and centrifuged, and the supernatant (globulin) was collected, precipitated with acetone, homogenized and stored overnight in a freezer. The solution was centrifuged, and the supernatant (acetone) discarded. The pellet (globulin) was stored in a freezer for subsequent analysis on SDS-Page. For prolamin extraction, $500 \mu \mathrm{L}$ of isopropanol $60 \%(\mathrm{v} / \mathrm{v})$ was added to the rice flour, as described by Turley \& Ching (1986), with modifications. The solution was shaken and centrifuged, and the supernatant (prolamin) was precipitated, homogenized and stored in a freezer overnight. Then, the solution was thawed and centrifuged, and the supernatant (acetone) was discarded. The pellet (prolamin) was stored in a freezer for subsequent analysis on SDS-Page. For glutelin extraction, $700 \mu \mathrm{L}$ of extraction buffer was added to the flour, as described by Kawakatsu et al. (2008). This solution was shaken vigorously for two hours and centrifuged for $15 \mathrm{~min}$ at $4^{\circ} \mathrm{C}$. The supernatant (glutelin) was collected in a new tube and precipitated with $1.5 \mathrm{~mL}$ of acetone, homogenized by inversion and stored in a freezer overnight. The solution was centrifuged and the supernatant (acetone) was discarded. The pellet (glutelin) was stored in a freezer for subsequent analysis on SDS-Page.

The analyses of total protein and fraction profile were performed in a denaturing polyacrylamide gel (SDS-Page), in a discontinuous buffer system, with $4.5 \%$ stacking gel and $14 \%$ resolving gel. Gels were subjected to electrophoresis at $80 \mathrm{~mA}$ for approximately three hours, using the Rubi SE 600 system (GE Healthcare, Waukesha, WI, USA). Then, gels were stained with coomassie blue and destained in 5\% methanol (v/v), 7\% acetic acid (v/v) and 88\% water. Finally, gels were photographed using a digital camera Sony Cybershot DSC-P200, (Sony Brasil, São Paulo, SP, Brazil). From the images, the protein profiles were compared using the DNA Simdex 3 beta release software program (Scott Archer and GenetX, cid. Jamestown, CO, USA), which determines the molecular weight of each band from the positions of the marker bands at the low-molecular weight pattern using a Amersham (LMW calibration kit for SDS electrophoresis, GE Healthcare São Paulo, SP, Brazil).

\section{Results and Discussion}

Significant differences between the accessions of the wild rice species $O$. glumaepatula were found for total protein and protein fractions (Table 2). Total protein levels were divided into four groups, with ranges from $14.94 \%$ (wild genotype BGA14280) to $9.07 \%$ (BGA14179). The control cultivars BRS Bonança 
and Primavera, together with the wild accessions BGA14210, BGA14232, BGA14233, and BGA14179, showed the lowest levels of total protein (Table 2).

Kennedy \& Burlingame (2003) analyzed the protein contents of 2,869 genotypes of rice $(2,674 \mathrm{O}$. sativa and 195 O. glaberrima), and found $8.8 \%$ as the mean for $O$. sativa, ranging from 4.5 to $15.9 \%$. The mean score for $O$. glaberrima was $13.6 \%$, ranging from 10.2 to $15.9 \%$, which was similar to the values found here for the wild species $O$. glumaepatula. Cao et al. (2009) found a wide variation in the levels of storage protein

Table 2. Contents of storage protein and of protein fractions in 29 Oryza glumaepatula accessions and in two O. sativa cultivars $^{(1)}$.

\begin{tabular}{|c|c|c|c|c|c|}
\hline \multirow{3}{*}{$\begin{array}{l}\text { Genotypes } \\
\text { BGA14280 }\end{array}$} & \multicolumn{3}{|c|}{ Total protein Albumin Globulin } & \multirow[t]{2}{*}{ Prolamin } & \multirow{2}{*}{ Glutelin } \\
\hline & & & 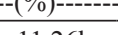 & & \\
\hline & $14.94 a$ & $4.46 \mathrm{c}$ & $11.26 \mathrm{~b}$ & $6.88 \mathrm{a}$ & $77.38 \mathrm{c}$ \\
\hline BGA14187 & $14.89 \mathrm{a}$ & $5.83 b$ & $9.28 \mathrm{c}$ & $6.94 \mathrm{a}$ & $77.93 \mathrm{c}$ \\
\hline BGA14208 & $14.53 \mathrm{a}$ & $3.68 \mathrm{~d}$ & $7.36 \mathrm{~d}$ & $4.62 b$ & $84.33 \mathrm{a}$ \\
\hline BGA14197 & $14.22 \mathrm{a}$ & $3.65 \mathrm{~d}$ & $8.10 \mathrm{~d}$ & $5.26 b$ & $82.97 \mathrm{a}$ \\
\hline BGA14201 & $14.19 \mathrm{a}$ & $4.78 \mathrm{c}$ & $7.25 \mathrm{~d}$ & $6.05 b$ & $81.90 \mathrm{~b}$ \\
\hline BGA14137 & $14.06 \mathrm{a}$ & $3.60 \mathrm{~d}$ & $6.25 \mathrm{~d}$ & $5.42 b$ & $84.76 \mathrm{a}$ \\
\hline BGA14207 & $13.98 \mathrm{a}$ & $4.77 \mathrm{c}$ & $6.62 d$ & $5.22 b$ & $83.37 \mathrm{a}$ \\
\hline BGA14200 & $13.35 b$ & $6.18 b$ & $8.39 \mathrm{c}$ & $5.08 \mathrm{~b}$ & $80.32 b$ \\
\hline BGA14268 & $13.13 b$ & $4.55 \mathrm{c}$ & $7.88 \mathrm{~d}$ & $5.91 b$ & $81.68 \mathrm{c}$ \\
\hline BGA14204 & $12.92 \mathrm{~b}$ & $4.74 \mathrm{c}$ & $8.52 \mathrm{c}$ & $6.58 \mathrm{a}$ & $80.14 b$ \\
\hline BGA14205 & $12.90 \mathrm{~b}$ & $4.00 \mathrm{~d}$ & $7.64 d$ & $4.93 b$ & $83.42 \mathrm{a}$ \\
\hline BGA14198 & $12.81 \mathrm{~b}$ & $3.98 \mathrm{~d}$ & $9.62 \mathrm{c}$ & $6.19 b$ & $80.20 \mathrm{~b}$ \\
\hline BGA14202 & $12.60 \mathrm{~b}$ & $3.90 \mathrm{~d}$ & $8.11 \mathrm{~d}$ & $5.21 \mathrm{~b}$ & $82.76 \mathrm{a}$ \\
\hline BGA14160 & $12.47 \mathrm{~b}$ & $5.38 b$ & $12.69 \mathrm{~b}$ & $7.63 \mathrm{a}$ & $74.28 \mathrm{c}$ \\
\hline BGA14188 & $12.42 \mathrm{~b}$ & $5.00 \mathrm{~b}$ & $11.55 \mathrm{~b}$ & $7.11 \mathrm{a}$ & $76.31 \mathrm{c}$ \\
\hline BGA14203 & $12.30 \mathrm{~b}$ & $5.20 \mathrm{~b}$ & $9.03 \mathrm{c}$ & $6.74 \mathrm{a}$ & $79.01 \mathrm{c}$ \\
\hline BGA14269 & $11.79 \mathrm{c}$ & $3.33 \mathrm{~d}$ & $6.64 d$ & $4.62 b$ & $85.40 \mathrm{a}$ \\
\hline BGA14186 & $11.50 \mathrm{c}$ & $4.57 \mathrm{c}$ & $10.42 \mathrm{~b}$ & $4.94 b$ & $80.09 \mathrm{~b}$ \\
\hline BGA14270 & $11.42 \mathrm{c}$ & $5.74 \mathrm{~b}$ & $9.75 \mathrm{c}$ & $5.43 b$ & $79.07 \mathrm{c}$ \\
\hline BGA14162 & $11.05 \mathrm{c}$ & $3.86 \mathrm{~d}$ & $14.48 \mathrm{a}$ & $8.68 \mathrm{a}$ & $72.96 \mathrm{~d}$ \\
\hline BGA14196 & $11.01 \mathrm{c}$ & $4.43 c$ & $7.89 \mathrm{~d}$ & $6.01 \mathrm{~b}$ & $81.64 \mathrm{~b}$ \\
\hline BGA14206 & $10.79 \mathrm{c}$ & $4.31 \mathrm{c}$ & $7.15 \mathrm{~d}$ & $6.38 \mathrm{a}$ & $82.15 b$ \\
\hline BGA14170 & $10.65 \mathrm{c}$ & $4.63 c$ & $8.36 \mathrm{c}$ & $8.37 \mathrm{a}$ & $78.64 \mathrm{c}$ \\
\hline BGA14199 & $10.50 \mathrm{c}$ & $5.29 \mathrm{~b}$ & $6.74 d$ & $7.31 \mathrm{a}$ & $80.64 b$ \\
\hline BGA14195 & $10.28 \mathrm{c}$ & $4.07 \mathrm{~d}$ & $9.07 \mathrm{c}$ & $3.88 \mathrm{~b}$ & $82.96 \mathrm{~b}$ \\
\hline BGA14210 & $10.14 d$ & $11.07 \mathrm{a}$ & $7.18 \mathrm{~d}$ & $4.87 \mathrm{~b}$ & $76.86 \mathrm{c}$ \\
\hline BGA14232 & $9.81 \mathrm{~d}$ & $4.80 \mathrm{c}$ & $11.15 b$ & $8.01 \mathrm{a}$ & $76.04 \mathrm{c}$ \\
\hline BGA14233 & $9.13 \mathrm{~d}$ & $5.76 \mathrm{~b}$ & $10.71 \mathrm{~b}$ & $6.42 \mathrm{a}$ & $77.08 \mathrm{c}$ \\
\hline BGA14179 & $9.07 \mathrm{~d}$ & $5.20 \mathrm{~b}$ & $12.04 \mathrm{~b}$ & $5.83 \mathrm{~b}$ & $76.93 \mathrm{c}$ \\
\hline Primavera & $8.70 \mathrm{~d}$ & $4.42 \mathrm{c}$ & $9.27 \mathrm{c}$ & $6.23 \mathrm{a}$ & $80.07 \mathrm{~b}$ \\
\hline \multirow[t]{2}{*}{ BRS Bonança } & $8.65 \mathrm{~d}$ & $5.98 \mathrm{~b}$ & $14.42 \mathrm{a}$ & $6.13 b$ & $73.46 \mathrm{c}$ \\
\hline & \multicolumn{5}{|c|}{ Means } \\
\hline Wild rice accessions & 12.17 & 4.86 & 9.01 & 6.09 & 80.04 \\
\hline Cultivars & 8.68 & 5.2 & 11.85 & 6.18 & 76.77 \\
\hline
\end{tabular}

${ }^{(1)}$ Means followed by equal letters do not differ by the Scott-Knott test, at $5 \%$ probability. content (7.38-15.41\%) in Chinese varieties of rice (O. sativa). Silveira et al. (2010) found a range of 4.4$20.2 \%$ for storage protein contents of 550 accessions, in the rice Core Collection of Embrapa, with an average of $10.31 \%$, lower than the average found here $(12.17 \%)$ for O. glumaepatula. These authors proposed a classification as to the protein contents: high $(\geq 12 \%)$, medium (11.9-9\%), and low $(\leq 8.9 \%)$. From the 29 genotypes evaluated in the present study, 16 genotypes had high-total protein contents and $13 \mathrm{had}$ medium-total protein contents (Table 2), according to this classification.

Oryza glumaepatula accessions showed higher levels of albumin (BGA14210) and glutelin (BGA14208, BGA14197, BGA14137, BGA14207, BGA14205, BGA14202 and 14269) than the two evaluated cultivars. However, no difference was found between the high levels of globulin found in the accession BGA14162 and the ones determined in the 'BRS Bonança'. Similarly, 'Primavera' did not differ from the 12 accessions of $O$. glumaepatula (Table 2) with the highest prolamin contents. Other studies reported similar results for protein fractions contents in these O. sativa cultivars (Agboola et al., 2005; Cao et al., 2009). These results denote that O.glumaepatula equalize, at least, the highest levels of protein fractions found in cultivated rice.

The wild accessions evaluated here had $\alpha$-glutelin levels at 40, 39, 38, 36, 37 and 35-34 $\mathrm{kDa}$, while BRS Bonança and Primavera cultivars, at 39,37 , and $35 \mathrm{kDa}$ (Figure 1). Jahan et al. (2001) analyzed the total proteins of $O$. sativa by SDS-Page and found $\alpha$-glutelin proteins with 39,38 , and $37 \mathrm{kDa}$. BGA14232 had no $\alpha$-glutelin of 37 or $38 \mathrm{kDa}$, showing a profile with differential $\alpha$-polypeptides. Moreover, this genotype had $\alpha$-glutelin at $39 \mathrm{kDa}$, which was also present in BRS Bonança and Primavera cultivars. Alpha-glutelin with $37 \mathrm{kDa}$ was present in 17 genotypes of $O$. glumaepatula, as well as in the two $O$. sativa cultivars. Seven wild genotypes showed $\alpha$-glutelin with $36 \mathrm{kDa}, 19$ showed $\alpha$-glutelin with 34-35 kDa, and BGA14137, BGA14208 and BGA14203 had no $\alpha$-glutelin with sizes of 35 or $36 \mathrm{kDa}$.

All accessions of O. glumaepatula showed a differential $\alpha$-polypeptide of $40 \mathrm{kDa}$, which was not found in BRS Bonança and Primavera (Figure 1). When SDS-Page was performed with protein fractions, the results were similar to those found in 
electrophoresis for total protein. For instance, the wild genotypes had $\alpha$-glutelin ranging from 34 to $40 \mathrm{kDa}$ (Figure $2 \mathrm{D}$ ). Oryza glumaepatula genotypes had $\alpha$-glutelin with $40 \mathrm{kDa}$, which was not found for the two cultivars of $O$. sativa. Considering the diversity of $\alpha$-glutelin found in O. glumaepatula, we propose the following classification for this fraction: glutelin $\alpha-1$ (40 kDa); $\alpha-2(39 \mathrm{kDa}) ; \alpha-3(38 \mathrm{kDa})$; $\alpha-4(37 \mathrm{kDa}) ; \alpha-5(36 \mathrm{kDa})$; and $\alpha-6(34$ or $35 \mathrm{kDa})$. $\beta$-glutelin had poor resolution and could not be separated by SDS-Page. However, its molecular weight was 19 to $21 \mathrm{kDa}$ in the wild genotypes and cultivars evaluated; these values were similar to but lower than those reported by Jahan et al. (2001), who found $\beta$-glutelin proteins at 23, 22.5, and $22 \mathrm{kDa}$. The gels have also shown proteins with a molecular mass

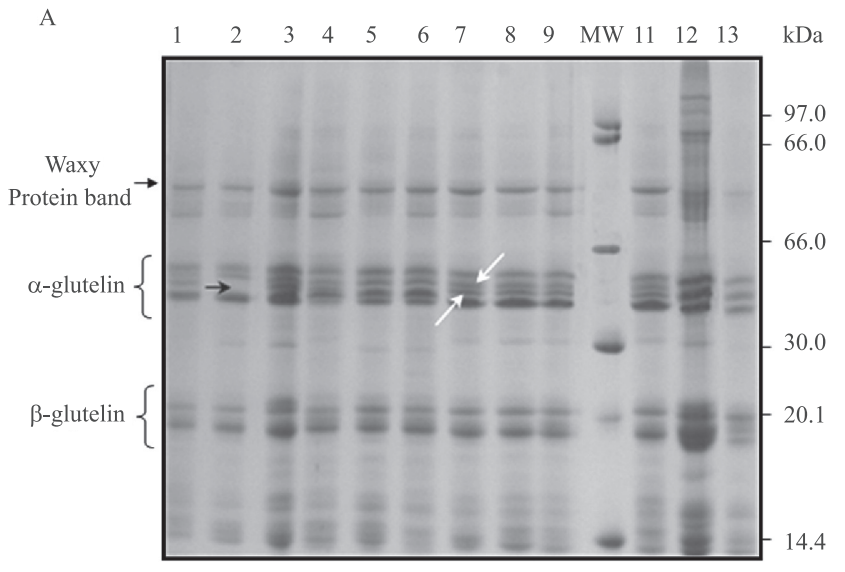

B

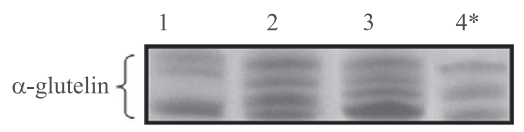

Figure 1. SDS-Page of seed total protein, obtained in Oryza glumaepatula and in the O. sativa cultivars BRS Bonança and Primavera. A: lane 1, BGA14233; lane 2, BGA14232; lane 3, BGA14280; lane 4, BGA14160; lane 5, BGA14162; lane 6, BGA14170; lane 7, BGA14179; lane 8, BGA14186; lane 9, BGA14187; MW, Molecular mass marker in kilodaltons; lane 11, BGA14188; lane 12, 'BRS Bonança'; lane 13, 'Primavera'. Black arrow inside the Figure indicates a differential profile with the absence of $\alpha$-glutelin at 37 and $38 \mathrm{kDa}$, shown with the white arrows. The band corresponding to waxy protein is indicated in the gel. B: highlighted $\alpha$-glutelin region from the gel image A for: lane 1, BGA14232; lane 2, BGA14162; lane 3, BGA14170; lane 4, Primavera. of approximately $60 \mathrm{kDa}$; these proteins are likely to be waxy proteins, related to the synthesis of starch (Kawakatsu et al., 2008).

Albumin fraction of $O$. glumaepatula genotypes showed high (97-52 kDa), medium (41-30 kDa), and low $(25-15 \mathrm{kDa})$ molecular masses. The profile of the albumin fraction was similar among wild genotypes, and different from $O$. sativa. The wild genotypes showed a band with a molecular mass of approximately $18 \mathrm{kDa}$, while the cultivars BRS Bonança and Primavera did not showed such proteins, or had them at such low concentrations that they could not be detectable (Figure 2 A). Nevertheless, globulin profile between $O$. glumaepatula and rice cultivars was similar. Furthermore, the wild genotypes and the rice cultivars showed very intense bands at approximately $25 \mathrm{kDa}$ (Figure $2 \mathrm{~B}$ ). Chandi \& Sogi (2007) also found a wide range of molecular weights for $O$. sativa, with variations from 24 to $96 \mathrm{kDa}$ for albumin, and from 23 to $118 \mathrm{kDa}$ for globulin.

Prolamin showed a similar band pattern among rice cultivars and wild rice, and was characterized by low-molecular-weight proteins $(18-15 \mathrm{kDa})$ (Figure 2 C). Van Der Borght et al. (2006) found prolamin between 16 and $10 \mathrm{kDa}$, which were similar to the values observed in $12 \mathrm{O}$. glumaepatula genotypes. Chandi \& Sogi (2007) found slightly larger prolamin, with molecular masses of 28-24 kDa.

Accessions of $O$. glumaepatula showed higher levels of all measured amino acids, in comparison with the two cultivars of $O$. sativa, except for tryptophan. Considering the average, only methionine and tryptophan showed higher values in $O$. sativa, while isoleucine had the same mean values between the two species. In both species, there was a predominance of glutamic acid and aspartic acid. A relevant fact is that lysinelevels were higherin O. glumaepatula. This amino acid is considered to be important for the digestibility of food and for its nutritional quality (Huebner et al., 1990). The accessions of $O$. glumaepatula that had the highest levels of amino acids were BGA14207 (for seven amino acids), BGA14208 (for eight amino acids), and BGA14280 (for two amino acids) (Table 3). BGA14207 and BGA14208 came from two distinct populations collected in Roraima state, Brazil; while BGA14280 came from Goiás state. These three accessions can be used in rice breeding programs to increase grain nutritional quality. 


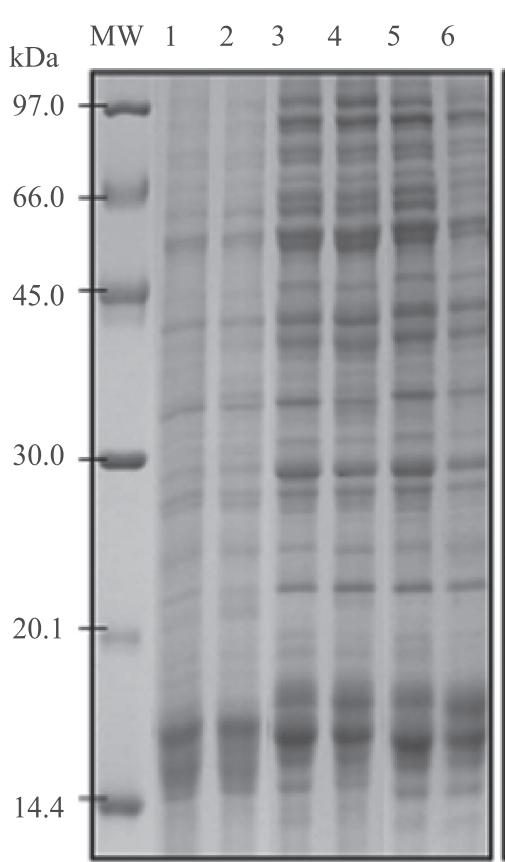

A) Albumin

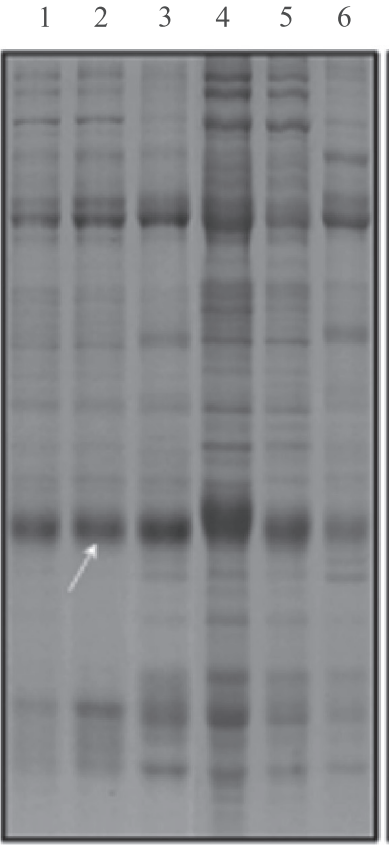

B) Globulin

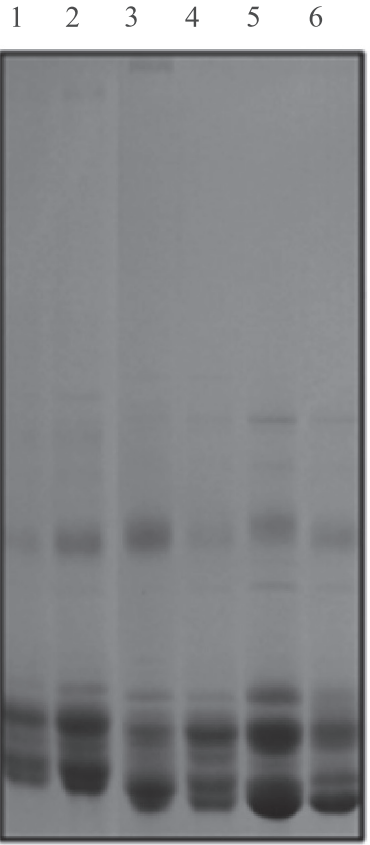

C) Prolamin

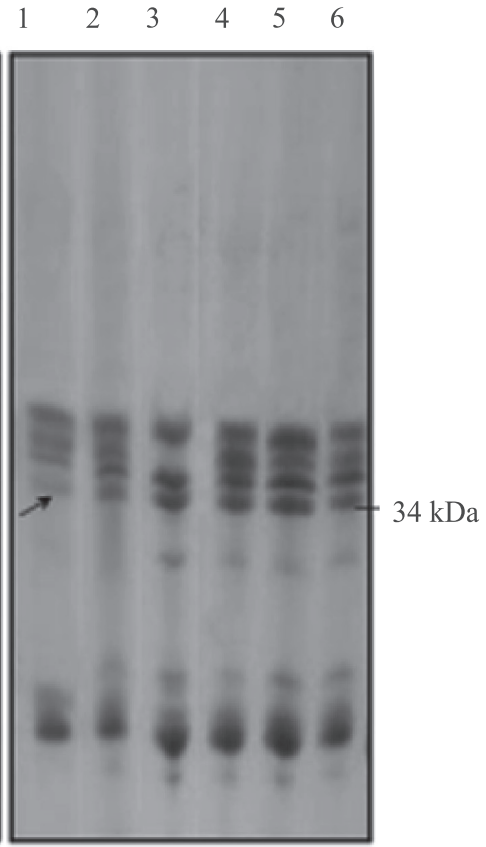

D) Glutelin

Figure 2. SDS-Page of seed protein fractions, extracted in the wild rice Oryza glumaepatula and in the $O$. sativa cultivars Bonança and Primavera . MW: molecular mass marker in kilodaltons. A: lane 1, O. sativa BRS Bonança; lane 2, O. sativa Primavera; lane 3, O. glumaepatula BGA14208; lane 4, BGA14207; lane 5, BGA14162; lane 6, BGA14187. B: lane 1, Primavera; lane 2, BRS Bonança; lane 3, BGA14162; lane 4, BGA14280; lane 5, BGA14232; lane 6, BGA14160. C: lane 1, Primavera; lane 2, BRS Bonança; lane 3, BGA14170; lane 4, BGA14179; lane 5, BGA14280; lane 6, BGA14233. D: lane 1, BRS Bonança; lane 2, Primavera; lane 3, BGA14232; lane 4, BGA14187; lane 5, BGA14268; lane 6, BGA14197. White arrow indicates the band at $25 \mathrm{kDa}$. Black arrow indicates the band at $34 \mathrm{kDa}$.

Table 3. Levels of total amino acids ( $\mathrm{g}$ per $100 \mathrm{~g}$ ) determined in grains of Oryza glumaepatula (OG) and O. sativa (OS).

\begin{tabular}{lccccc}
\hline Amino acid & Maximum & Minimum & Mean & OS & OG \\
\hline Aspartic acid & 1.31 (BGA14207) & 0.84 (B) & 1.06 & 0.87 & 1.11 \\
Glutamic acid & 2.76 (BGA14207) & $1.76(\mathrm{~B})$ & 2.23 & 1.81 & 2.35 \\
Serine & 0.68 (BGA14207) & $0.47(\mathrm{~B})$ & 0.58 & 0.49 & 0.61 \\
Glycine & 0.53 (BGA14207) & $0.44(\mathrm{~B})$ & 0.48 & 0.46 & 0.48 \\
Histidine & 0.37 (BGA14207) & $0.22(\mathrm{~B})$ & 0.30 & 0.23 & 0.32 \\
Arginine & 1.14 (BGA14207) & $0.85(\mathrm{~B})$ & 0.96 & 0.88 & 0.98 \\
Threonine & 0.55 (BGA14207) & $0.38(\mathrm{~B})$ & 0.46 & 0.40 & 0.48 \\
Alanine & 0.71 (BGA14280) & $0.55(\mathrm{~B})$ & 0.64 & 0.57 & 0.67 \\
Proline & 0.60 (BGA14208) & $0.46(\mathrm{~B})$ & 0.52 & 0.48 & 0.53 \\
Tyrosine & 0.72 (BGA14280) & $0.49(\mathrm{~B})$ & 0.60 & 0.53 & 0.62 \\
Valine & 0.78 (BGA14208) & $0.56(\mathrm{~B})$ & 0.65 & 0.57 & 0.68 \\
Methionine & 0.26 (BGA14208) & $0.23(\mathrm{~B})$ & 0.23 & 0.24 & 0.23 \\
Cysteine & 0.34 (BGA14208) & $0.17(\mathrm{P})$ & 0.25 & 0.19 & 0.27 \\
Isoleucine & 0.59 (BGA14208) & $0.50(\mathrm{~B})$ & 0.51 & 0.51 & 0.51 \\
Leucine & 1.17 (BGA14208) & $0.83(\mathrm{~B})$ & 1.00 & 0.85 & 1.05 \\
Phenylalanine & 0.88 (BGA14208) & $0.57(\mathrm{~B})$ & 0.67 & 0.58 & 0.70 \\
Lysine & 0.50 (BGA14208) & $0.33(\mathrm{P})$ & 0.42 & 0.34 & 0.45 \\
Tryptophan & 0.16 (BRS Bonança) & $0.15(\mathrm{P})$ & 0.11 & 0.16 & 0.10 \\
\hline Total & 14.05 & 9.8 & 11.68 & 10.10 & 12.14 \\
\hline
\end{tabular}

(1) In brackets is the identification of genotype in which the value was found. B, 'BRS Bonanza'; P, 'Primavera'.

\section{Conclusions}

1. Oryza glumaepatula accessions have high levels of total protein, albumin and glutelin fractions, and amino acids (excepting for tryptophan), equalizing, at least, the highest levels found in the commercial cultivars.

2. Albumin and glutelin profiles are distinct between rice and $O$. glumaepatula

3. Oryza glumaepatula has potential to increase the nutritional quality of rice storage protein through interspecific crosses.

\section{Acknowledgments}

To Coordenação de Aperfeiçoamento de Pessoal de Nível Superior (Capes), for the scholarship granted; and Conselho Nacional de Desenvolvimento Científico e Tecnológico (CNPq), for the financial support. 


\section{References}

AGBOOLA, S.; DARREN, N.G.; MILLS, D. Characterization and functional properties of Australian rice protein isolates. Journal of Cereal Science, v.41, p.283-290, 2005. DOI: 10.1016/j. jes.2004.10.007.

BRADFORD, M.M. A rapid and sensitive method for the quantitation of microgram quantities of protein utilizing the principle of dye binding. Analytical Biochemistry, v.72, p.248-254, 1976. DOI: 10.1016/0003-2697(76)90527-3.

BRONDANI, R.P.V.; ZUCCHI, M.I.; BRONDANI, C.; RANGEL, P.H.N.; BORBA, T.C. de O.; RANGEL, P.N.; MAGALHÃES, M.R.; VENCOVSKY, R. Genetic structure of wild rice Oryza glumaepatula populations in three Brazilian biomes using microsatellite markers. Genetica, v.125, p.115-123, 2005. DOI: 10.1007/s10709-005-4916-4.

CAO, X.; WEN, H.; LI, C.; GU, Z. Differences in functional properties and biochemical characteristics of congenetic rice proteins. Journal of Cereal Science, v.50, p.184-189, 2009. DOI: 10.1016/j.jcs.2009.04.009.

CHANDI, G.K.; SOGI, D.S. Biochemical characterization of rice protein fractions. International Journal of Food Science and Technology, v.42, p.1357-1362, 2007. DOI: 10.1111/j.13652621.2006.01340.x.

CRUZ, C.D. Programa Genes: aplicativo computacional em genética e estatística. Viçosa: Universidade Federal de Vicosa, 2001 .

HAGEN, S.R.; FROST, B.; AUGUSTIN, J. Precolumn phenylisothiocyanate derivatization and liquid chromatography of amino acids in food. Journal of the Association of Official Analytical Chemists, v.72, p.912-916, 1989.

HALFORD, N.G.; SHEWRY, P.R. Cereal seed storage proteins: structures, properties and role in grain utilization. Journal of Experimental Botany, v.53, p.947-958, 2002. DOI: 10.1093/ jexbot/53.370.947.

HUEBNER, F.R.; BIETZ, J.A.; JULIANO, B.O. Rice cultivar identification by high-performance liquid chromatography of endosperm proteins. Cereal Chemistry, v.67, p.129-135, 1990.

JAHAN, M.S.; KUMMARU, T.; SATOH, H.; HAMID, A. Variation of glutelin seed storage protein in Bangladesh rice cultivars. Rice Genetics Newsletter, v.18, p.43-46, 2001.

KATSUDE-TANAKA, T.; DULDULAO, J.B.A.; KIMURA, Y.; IIDA, S.; YAMAGUCHI, T.; NAKANO, J.; UTSUMI, S. The two subfamilies of rice glutelin differ in both primary and higher-order structures. Biochimica et Biophysica Acta, v.1699, p.95-102, 2004.

KAWAKATSU, T.; YAMAMOTO, P.M.; HIROSE, S.; YANO, M.; TAKAIWA, F. Characterization of a new rice glutelin gene glud-1 expressed in the starchy endosperm. Journal of Experimental Botany, v.59, p.4233-4245, 2008. DOI: 10.1093/jxb/ern265.

KENNEDY, G.; BURLINGAME, B. Analysis of food composition data on rice from a plant genetic resources perspective. Food Chemistry, v.80, p.589-596, 2003. DOI: 10.1016/S03088146(02)00507-1.

KIM, S.T.; WANG, Y.; KANG, S.Y.; KIM, S.G.; RAKWAL, R.; KIM, Y.C.; KANG, K.Y. Developing rice embryo proteomics reveals essential role for embryonic proteins in regulation of seed germination. Journal of Proteome Research, v.8, p.3598-3605, 2009. DOI: $10.1021 /$ pr900358s.

KOMATSU, S. Plant proteomics databases: their status in 2005. Current Bioinformatics, v.1, p.33-36, 2006. DOI: 10.2174/157489306775330651.

KOMATSU, S.; TANAKA, N. Rice proteome analysis: a step toward functional analysis of the rice genome. Proteomics, v.4, p.938-949, 2005. DOI: 10.1002/pmic.200401040.

NATIONAL INSTITUTE OF AGROBIOLOGICAL SCIENCES. Rice Proteome Database. 2002. Available at: $<$ http://gene64.dna. affrc.go.jp/RPD/>. Accessed on: 28 Jan. 2012.

NAVES, M.M.V.; BASSINELLO, P.Z. Importância na nutrição humana. In: SANTOS, A.B. dos; STONE, L.F.; VIEIRA, N.R. de A. (Ed.). A cultura do arroz no Brasil. 2.ed. ver. ampl. Santo Antônio de Goiás: Embrapa Arroz e Feijão, 2006. p.17-30.

RANGEL, P.N.; BRONDANI, R.P.V.; RANGEL, P.H.N.; BRONDANI, C. Agronomic and molecular characterization of introgression lines from the interspecific cross Oryza sativa (BG 90-2) x Oryza glumaepatula (RS-16). Genetics and Molecular Research, v.7, p.184-195, 2007. DOI: 10.4238/ vol7-1gmr406.

SHOTWELL, M.A.; LARKINS, B.A. The biochemistry and molecular biology of seed storage proteins. The Biochemistry of Plants: a Comprehensive Treatise, v.15, p.297-345, 1989.

SILVEIRA, R.D.D; SANTOS, K.F.E.N.; MARTIM-DIDONET, C.C.G.; DIDONET, A.D.; BRONDANI, C. Proteínas de reserva de acessos de coleção nuclear de arroz. Pesquisa Agropecuária Brasileira, v.45, p.1441-1447, 2010. DOI: 10.1590/S0100204X2010001200015.

TURLEY, R.H.; CHING, T.M. Storage protein accumulation in 'Scio' barley seed as affected by late foliar applications of nitrogen. Crop Science, v.26, p.778-782, 1986. DOI: 10.2135/cropsci1986.0 011183X002600040032x.

VAN DER BORGHT, A.; VANDEPUTTE, G.E.; DERYCKE, V.; BRIJS, K.; DAENEN, G.; DELCOUR, J.A. Extractability and chromatographic separation of rice endosperm proteins. Journal of Cereal Science, v.44, p.68-74, 2006. DOI: 10.1016/j. jcs.2006.03.005.

Received on May 30, 2012 and accepted on January 15, 2013 